\title{
Estudo Comparativo da Sobrevivência de Bactérias Probióticas em Extratos Hidrossolúveis de Soja Verde e Madura
}

\author{
Erica Sayuri Ichimura (I), Carolina Battistini (I), José Ubirajara Vieira \\ Moreira (II), Leo Kunigk (I), Eliana Paula Ribeiro (I), Cynthia \\ Jurkiewicz Kunigk (I) \\ (I) IMT - Instituto Mauá de Tecnologia (Praça Mauá, 1 - São Caetano do Sul/SP), (II) EMBRAPA \\ Soja - Empresa Brasileira de Pesquisa Agropecuária (Rodovia Carlos João Strass, s/no - \\ Londrina/PR)
}

\section{Resumo}

Com o aumento na demanda por produtos para consumidores que apresentam restrição à ingestão de leite e derivados lácteos, alimentos com soja têm sido desenvolvidos como substituto das proteínas de origem animal, já que este grão contém todos os aminoácidos essenciais. A soja verde, por sua vez, possui sabor mais adocicado do que sua versão madura, devido aos teores mais elevados de sacarose e frutose, além de menor quantidade de oligossacarídeos, apresentando melhor digestibilidade. A fermentação do extrato hidrossolúvel de soja, por bactérias láticas e probióticas, tem sido utilizada para acrescentar propriedades funcionais ao produto e melhorar suas características sensoriais. O objetivo deste trabalho foi avaliar a sobrevivência das bactérias probióticas, Lactobacillus acidophilus e Bifidobacterium animalis em extratos hidrossolúveis de soja verde e madura fermentados. As sojas verde e madura utilizadas na produção dos extratos hidrossolúveis foram da cultivar BRS 232, desenvolvida pela Embrapa Soja, de Londrina. O processo de obtenção do extrato de soja madura consistiu na maceração dos grãos a $80{ }^{\circ} \mathrm{C}$ por 2 horas em água filtrada, seguida pela cominuição dos grãos, na proporção mássica de 1:6 (soja:água) e aquecimento a $100{ }^{\circ} \mathrm{C}$ por $10 \mathrm{~min}$. O extrato foi separado por filtração e pasteurizado $95{ }^{\circ} \mathrm{C}$ por 5 min. Para obtenção do extrato de soja verde, foi realizada a maceração dos grãos congelados em

\footnotetext{
Referência:

Erica Sayuri Ichimura, Carolina Battistini, José Ubirajara Vieira Moreira, Leo Kunigk, Eliana Paula Ribeiro, Cynthia Jurkiewicz Kunigk.Estudo Comparativo da Sobrevivência de Bactérias Probióticas em Extratos Hidrossolúveis de Soja Verde e Madura. In: Anais do $12^{\circ}$ Congresso Latinoamericano de Microbiologia e Higiene de Alimentos MICROAL 2014 [= Blucher Food Science Proceedings, num.1, vol.1]. São Paulo: Editora Blucher, 2014. DOI 10.5151/foodsci-microal-036
} 
água fervente por 5 minutos, descarte da água, cominuição com água na proporção mássica de 3:7 (soja:água), e por fim, a filtração. Para a fermentação, foi adicionada a cultura composta por Streptococcus thermophilus, L. acidophilus e B. animalis, e os extratos foram incubados a $37^{\circ} \mathrm{C}$, até atingir $\mathrm{pH} 4,8$. Após a etapa de fermentação, os extratos foram armazenados a $5{ }^{\circ} \mathrm{C}$ durante 29 dias. Analisando os resultados por ANOVA, verificou-se que o grau de maturação da soja não influenciou significativamente ( $p>0,05)$ o tempo de fermentação $(3,7 \pm 0,3 \mathrm{~h})$ e os valores de $\mathrm{pH}(4,6 \pm 0,1)$ durante o armazenamento. Entretanto, a acidez do extrato de soja madura variou significativamente (pL. acidophilus e B. animalis, permaneceram em $10^{7}$ e $10^{8} \mathrm{UFC} / \mathrm{mL}$, respectivamente, e tampouco foram influenciadas $(\mathrm{p}>0,05)$ pelo grau de maturação da soja. $\mathrm{O}$ grau de maturação da soja não influenciou significativamente a sobrevivência de microrganismos probióticos no extrato hidrossolúvel de soja durante 29 dias de armazenamento a $5^{\circ} \mathrm{C}$.

Palavras-Chave: Bebida fermentada, Probiótico, Soja, Soja verde Agência de Fomento: FAPESP 